\title{
A TURKISH BRONZE CANNON IN THE TOWER OF LONDON
}

BY

\author{
A. R. WILLIAMS and A. J. R. PATERSON
}

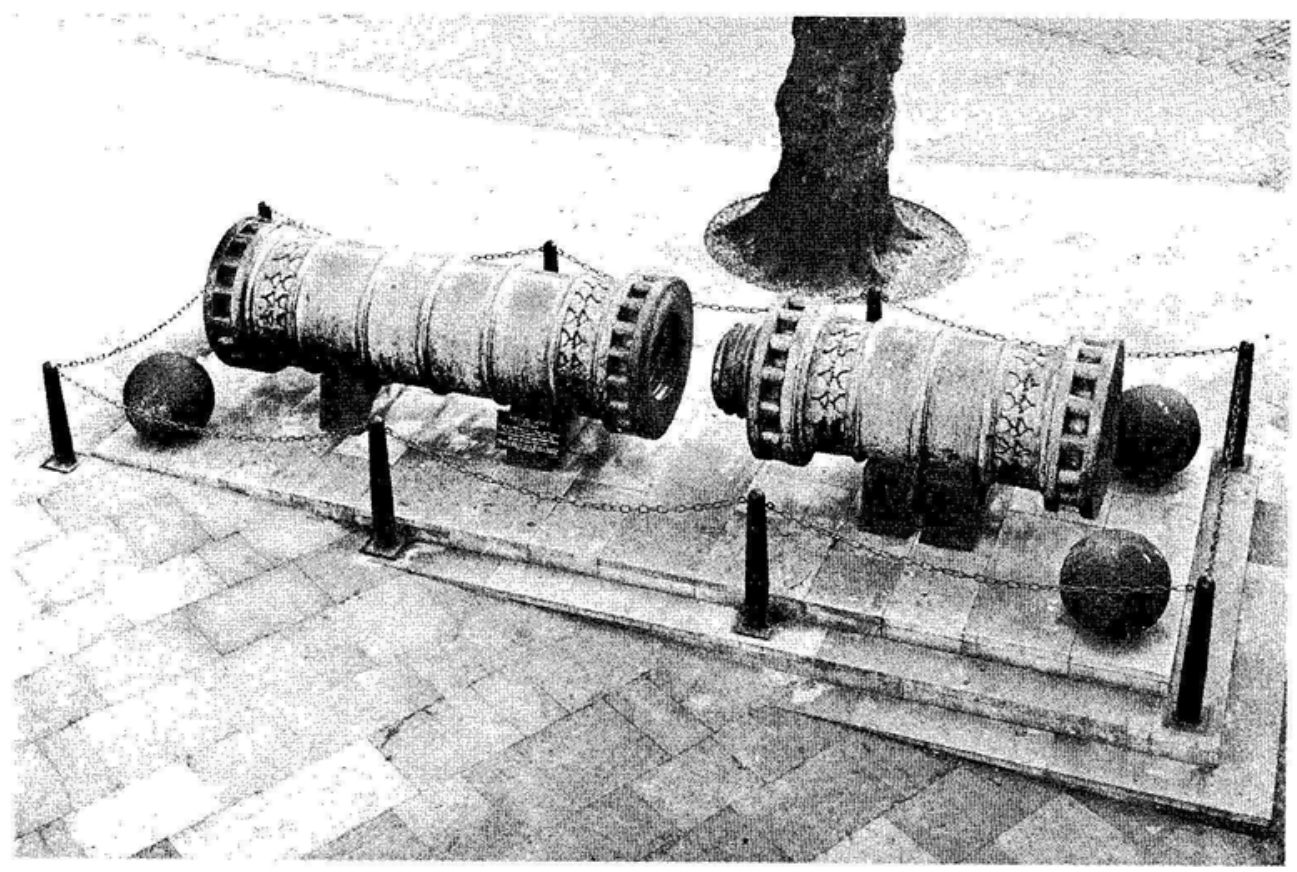

Great bronze gun from the Dardanelles, now in the Tower of London. Turkish, dated 1464. (Inventory number XIX.164.) Photograph: «British Crown Copyrightreproduced with permission of the Controller of Her Britannic Majesty's Stationery Office.» Length (complete), $518 \mathrm{~cm}$.; bore, $63.5 \mathrm{~cm}$.; weight breech, 8,942 kg.; weight barrel, $8,128 \mathrm{~kg}$; average weight of shot, $307 \mathrm{~kg}$.

WHEN the Ottoman Turks made Brusa in Asia Minor their capital in 1326, they were no more than a minor Asiatic military power, fighting as horse-archers as countless nomadic people before them, but within less than two hundred years, they had become the leading military power in 
Europe. The military technology of this extraordinary people has received comparatively little attention from historians. When they expanded their realm in to the Balkans, they adopted many of the techniques of Europcan warfare. The new elite of the army was a corps of foot-soldiers, the Janissaries (Yeni Cheri $=$ New Soldiers) founded in 1330 and recruited as a tax from Christian villages.

Four years after crossing over the Dardanelles, the Sultan Murad I made Adrianople his capital in 1360 and conquered the Serbs and Bulgars. A crusade was preached for the defence of Hungary but the Crusading army was defeated at Nicopolis in 1396.

In the next century the Turks used siege guns in 1422, and field artillery as early as 1448, if not before, at the second battle of Kossovo, where their opponents included Bohemian (Hussite) handgunners forced to seek service as mercenary troops after the end of the religious wars in Bohemia in 1436 . $^{1}$

To batter down the high stone walls of medieval castles, large siege guns were needed, and were effective because of their size and despite their clumsiness and inaccuracy. Murad II had had cannon cast for the siege of Hexamilion in 1446, and his son Muhammad II had a large number of bronce cannon of unprecedented size cast for the siege of Constantinople in 1453.

To capture the greatest city in the world, the most massive fortifications had to be breached. The near-contemporary account of Kritoboulos (1467) describes how the Sultan set about this:

(He) summoned the makers of his ordnance and discoursed with then on the guns, and on the defences, and what manner of cannon he needed the better to beat down the walls. The gunners replied that it would be easy to make a breach if they could make on the spot out of the guns they then possessed others large enough to overturn and demolish the rampart; but that to cast such pieces a considerable outlay was necessary, and above all a large supply of bronze. Muhammad commanded at once that they should have everything they required... (clay was mixed with linen and other fibres to reinforce it, then made into a cylindrical core) another exterior shape, to receive the first, was next made ready, hollow... but larger to leave a void space between the two. $1 \mathrm{t}$ is the space intended to receive the bronze pouring into it from the furnace to take the form of a cannon. This exterior is made of the same clay... surrounded with iron, timber, earth, and stones. Then they erected two furnaces, one on eithel side and close by for the foundry... and they cast into the foundry a mass of bronze and tin, about 1500 talents.*

1 P. WITtek, The carliest relerences to the use of fircarms by the Otlomans, an appendix to D. AyALON, Gunpoivder and firearms in the Mamluk kingdom, London, 1956, 141-144; C. W. C. Oman, A bistory of the art of war in the Middle Ages, JI, London, 1924, 356.

$*$ If one talent was approx. $60 \mathrm{lb}$. this would be about 40 tons. 
Thereupon they threw in charcoal and wood... (the bellows worked for three days and three nights) until the whole of the bronze, melted down and liquid, became as water. Then the outlets having been opened the bronze poured through earthen pipes into the mould until it was filled and the interior cylinder covered, and the metal one pic * in depth above it. ${ }^{2}$

Muhammad's master-gunfounder was one Urban or Orban, described as a «Hungarian,» and according to one account, he cast at least one of these great cannon at Adrianople, and then drawn the 120 miles (200 kilometres) to Constantinople by 50 pairs of oxen; a journey which took two months."

At the siege these cannon were loaded with stone balls, using closefitting wooden stoppers to retain the powder on ramming. They were fired from a bed of timber rather than a wheeled carriage and «sometimes knocked down all one section of the wall, sometimes half of it: sometimes more or less of one of the towcrs, or the great wall between two towers, or the battlements». ${ }^{4}$

Shortly after the capture of Constantinople, a gun-foundry (the Tōphāne) was established in the suburb of Galata, and which subsequently cast numerous guns of all sizes (except perhaps the very largest). The accounts of the Tophanne are in the process of being studied and cast much light on Ottoman foundry practice. ${ }^{5}$ For example, in the years 1522-26, the Tōphanne was supplied with 262 tons of copper and 29 tons of tin together with 229 tons of bronze as scrap, broken guns, etc. and from this were produced 625 small guns, 355 large guns, 32 «basilisks»** and various other items to a total weight of 481 tons. Disregarding the bronce recast, it would seem that copper was thought to need about $11 \%$ tin to casi a satisfactory gun. There were no suitable sources of tin within the Ottoman empire, and the Turks went to considerable trouble to buy this essential ingredient from foreign suppliers. ${ }^{6}$

At the siege of Scutari (Albania) in 1478, Muhammad set up 11 great siege guns firing stone shot, whose weight ranged from 370 to $1,640 \mathrm{lb}$.

$\because 27.9$ inches or $70.9 \mathrm{~cm}$.

${ }^{2}$ Kritoboulos, quoted by J. H. LeFroy, The greal cannon of Muhammad II, in: «Archaeological Journal», 25 (London, 1868), 261-280.

"C. Ffoulkes, The Dardanelles gun al the Tower, in: «Antiquaries' Journal», 10 (London, 1929), 217-227. On the journey from Adrianople, 218.

+ LeFroy, op. cil., 267.

'C. J. Hevwood, The activities of the statc cannon-foundry (Tōphana l'Amire) at Istanbul in tbe early sixlecatb century, conference paper published by the "Oriental Institute of Sarajevo», 30 (1980), 209-217.

$\therefore:$ Of unspecified size, but they cannot have been much more than 5 or 6 tons, from these numbers.

" V. I. PARry, Malerials of war in the Olloman empire, in: M. A. Cook (ed.), Sulies in the economic bistory of the Middle East, London, 1970, 219-229. 
( 165 to $750 \mathrm{~kg}$.) but it is unclear whether any of them were cast on site. At the first siege of Rhodes in 1480, Muhammad employed a battery of 16 guns called «double cannon» or «basilisks» which were apparently cast on site. They fired stone balls 2 or $3 \mathrm{ft} .(60 \mathrm{~cm}$. to $1 \mathrm{~m}$.) in diameter and so would seem to be much larger than weapons described as «basilisks» in the 16 th century. ${ }^{8}$

With the ebb of Turkish conquests, the great guns were employed in a more defensive role guarding the shores of the Dardanelles. Travellers in the 17 th- 18 th centuries mention at least 40 of them in the forts defending the Narrows, including one «20 feet long, made in two parts» and another larger still." The last time that these guns were fired in anger was in 1807 when an attacking squadron of British warships was driven off. In contrast, the Crimean War found Britain and the Ottoman Turks allies, and one of the great guns from the Dardanelles was presented to Queen Victoria.

According to Lefroy, the two-part gun of 25 inch bore was particularly requested, and it eventually arrived in England in 1868. At that time, there were still eighteen such guns in existence, and three similar (including one dated 1458) had just been broken up for scrap. Lefroy listed all their dimensions; their bores ranged from 20 to 30 inches $(50$ to $75 \mathrm{~cm}$.) and they fired stone shot ranging in weight from 436 to $1,245 \mathrm{lb}$. (200 to $565 \mathrm{~kg}.)^{13}$ At the start of this century eight of these guns were still in existence, but by 1919 only a couple survived, both made in one piece, i.e. muzzle-loaders."

The gun now at the Tower of London was made by one Munir Ali in 1464, according to the inscriptions thereon, and was made in two parts, the powder chamber unscrewing from the barrel for loading. It is 17 feet long $(5.2 \mathrm{~m}$.) its bore is 25 inches $(63 \mathrm{~cm}$.) and fired stone shot of approximately $650 \mathrm{lb} .(300 \mathrm{~kg} .)^{12}$

The authors were permitted by the Master of the Armouries to remove some specimens from the gun at the Tower for study. Eleven specimens (approx. $3 \mathrm{~mm}$. cubes) were removed from different places on the inner and outer surfaces of the gun where shown on figure 1 where this could be done inconspicuously, and examined by metallography. Their compositions were then determined by electron microanalysis.

7 LEFroY, op. cit., 273.

* Ibid., 270.

"Thévenot (1655) and Pococke (1740), quoted by Lefroy, op, cil, 262.

:" LeFroy, op. cit., 264.

"Foulkes, op cil., 224, and illustration pl. XXI.

${ }_{12}$ H. L. BLickmore, The Amouries of the Tower of London, vol. I: Ordnance, London, 1976. 


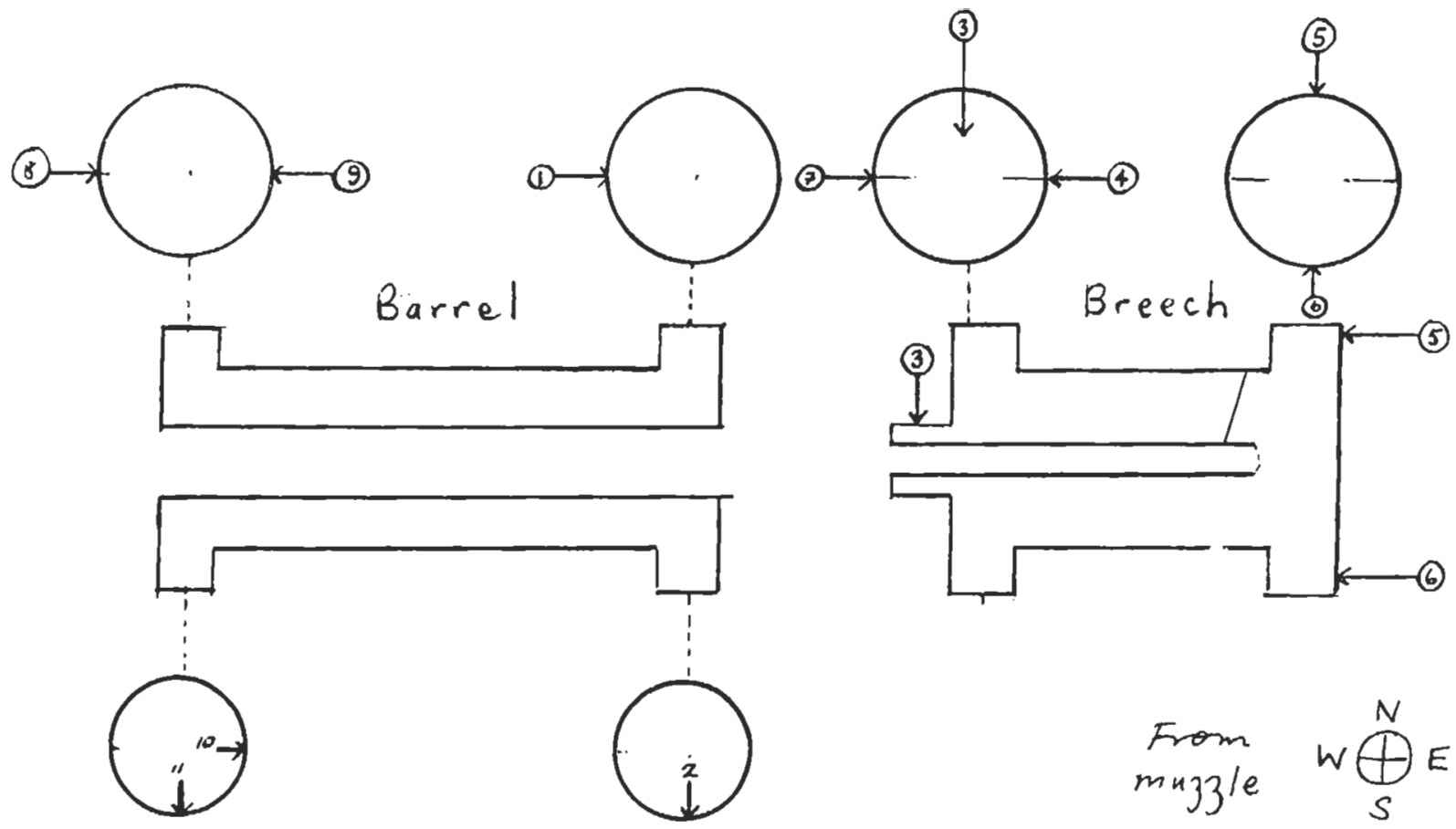

FIG. 1.-Diagram to show sampling of the cannon.

$\stackrel{\infty}{\infty}$ 
A chemical analysis was published by Abel in 1868 of samples taken from the surface-mouldings at either end of each part. He commented on the varying proportions of tin (from $4.8 \%$ to $10.1 \%$ ) which suggested to him a bronze rather low in tin, with traces of $\mathrm{Fe}, \mathrm{Pb}, \mathrm{Sb}, \mathrm{As}^{13}$ Leoni has also pointed out that the Greco-Roman horses of St. Mark's, Venice were cast from a bronze low in tin, but it must be observed that he was also constrained by having to sample only the surface. ${ }^{14}$

Riederer has recently published a series of analyses of bronze guns now in the Military History Museum in Vienna. Samples were taken taken from 254 guns, dating from the 16th to the 19th centuries, and analysed by atomic absorption spectroscopy. He was particularly interested in the $\mathrm{Pb}: \mathrm{Ag}$ ratios as a means of characterising certain foundries..$^{15}$ Of course, if guns were to be broken up and the fragments recast, then any such significant differences would be obliterated. Of 18 bronze guns cast in the 16th century in Vienna, Graz, Innsbruck, and Ragusa the tin content varied between $3.4 \%$ and $10.5 \%$, averaging $7.3 \%$.

The locations of the samples are not particularised, but assuming that they were all removed from the corresponding place on every gun, some valid conclusions may be drawn from these analytical results.

It is of course impossible to deduce the overall composition of any large heterogeneous object from its surface composition, and large castings will vary in composition, but nonetheless averages may be inferred and the nature of the variations may in themselves tell us how the objects were cast.

Let us consider what may happen when a $10 \%$ tin bronze is cast. While pure copper has a melting-point of $1,083^{\circ} \mathrm{C}$, i.e. at this temperature only, pure solid copper will pass directly to pure liquid copper, the presence of tin lowers the melting-point, and transforms a sharp meltingpoint into a range approx. $820^{\circ}-1,030^{\circ} \mathrm{C}$. So, when the temperature of the liquid alloy drops to $1,030^{\circ}$ a solid will start to separate. This will be a copper-rich solid solution $(\alpha)$ because a $2 \%$ tin bronze starts to melt at $1,030^{\circ}$, and a tin-rich solution will be left behind, which will have a lower melting-point. In the course of solidification then, the elements will be segregated, and the last to solidify may be other high-tin phases

"F. A. ABEL, Chemical composition of the great cannon of Mubammad 11, published as an appendix to LEFROY, op. cil., 279.

${ }^{1+}$ M. LEONI, Metallographic investigation of the borses of San Marco, in the exhibition catalogue The borses of San Marco (London, The Ruyal Academy, 1979), 190.199.

I: J. Rieverer, Die Zusammensetzung der Bronzegeschütze des Heeresgeschichtlicbun Museuns im Wiener Arsenal, in: «Berliner Beiträge zur Archäometrie», 2 (Berlin, 1977), 27-40. 
Barrel

Breech

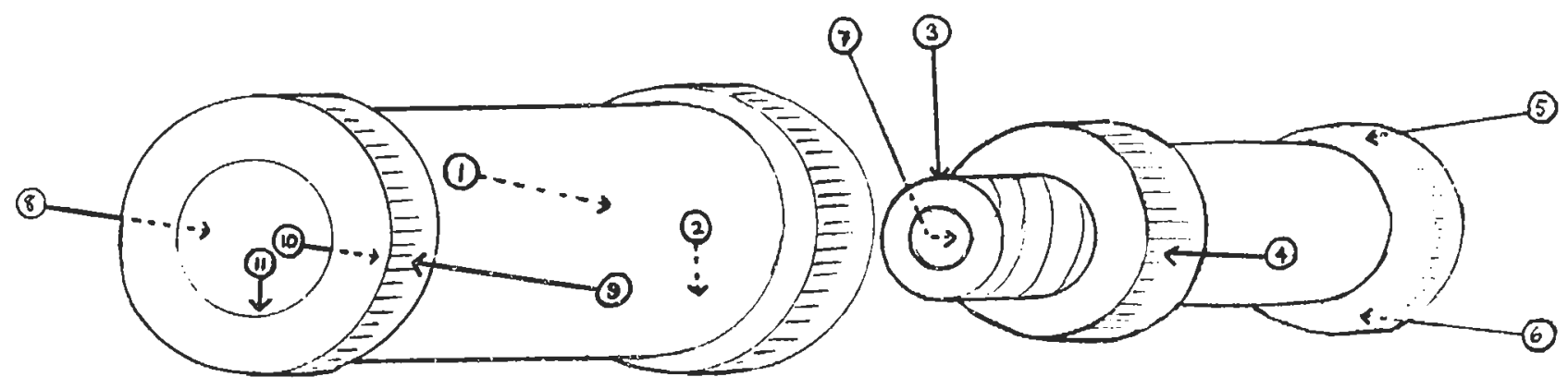

\begin{tabular}{|c|c|c|c|c|c|c|c|c|c|c|c|c|}
\hline SPECIMEA & 8 & 9 & 10 & $\|$ & 1 & 2 & 3 & 4 & 7 & 5 & 6 & \\
\hline MICROHACDNESS & 163 & 186 & $\varepsilon ;$ & 113 & 2238 & 237 & 232 & 160 & 145 & 198 & 257 & KG. $M M^{-2}$ \\
\hline
\end{tabular}

FIG. 2,-Diagram to show hardiness of specimens from cannon. 
(e.g. if half the bronze solidifies as $\alpha$, then the tin content of the rest will be $18 \%$, solidifying as a transitory $\beta$ phase which in turn decomposes to a mixture of $\alpha$ and $\delta$ phases). The slower the rate of solidification, i.e. the bigger the casting and the poorer the conductivity of the mould, the larger will be the dendritic («fern-like») crystals first formed; the composition of the dendrites will change continuously, and other phases will be deposited within the branches of the dendrites. As the bronze solidifies, its volume contracts, so that a mould will not be filled unless account has been taken of this shrinkage, and excess liquid is present in «risers» to make up the final volume. Because of tin's flowing down to try to fill crevices in the lower parts of the mould, the upper part may become depleted in tin. This was recognised by the 16th century if not much earlier, and Biringuccio (1540) describes the last-minute addition of a little excess tin to counteract this. "s Another cause of inconsistency may be the evolution of traces of gases, which become concentrated in the remaining liquid, and afflict the last parts of the casting to solidify with porosity.

The results obtained from the metallographic examination of the samples from the Dardanelles gun may be summarised:

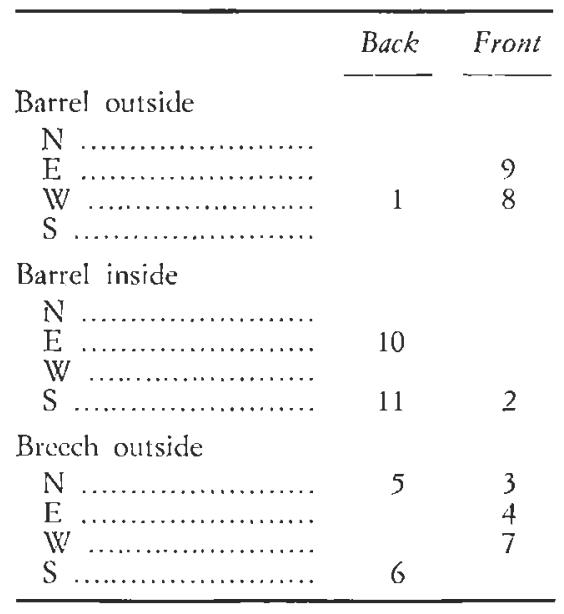

(looking at the muzzle, the horizontal and vertical axes of the gun barrel and breech are denoted by $N, E, S, W$ ).

". V. Biringuccio, Pirotechniu (Venice, 1540), trans. by C. S. Sinith and M. T. Gnudi, New York, 1942. 
What is visible in each sample is described in the captions to individual photomicrographs; but in every case includes the $\alpha$ solid solution of microhardness varying between 81 and $257 \mathrm{~kg} / \mathrm{mm}^{-2}$, together with sulphide inclusions, slag, numerous slip bands, and corrosion products. In the case of specimen 5 there is also a quantity of $\alpha \delta$ eutectoid, probably the result of a late addition of extra tin. Similar phases are also found in $4-6$.

There is little evidence of microporosity, or microsegregation («coring»). This is a tribute to the founder's skill, and perhaps the addition of traces of silver might have helped to refine the grain size, but this is speculation. If the casting were cooled very slowly then the, no doubt very large, dendrites may have had time to recrystallise so that annealing was not necessary.

What can be deduced from these results?

1. The similarity between specimens 8 and 9,4 and 7, as well as the presence of tin-rich phases in 5 and 6 confirm the written evidence that the two parts of the gun were cast vertically.

2. The back end of the barrel ( 1 and 2) is harder than the front end $(8,9,10$ and 11) presumably because it is richer in tin. This, and the presence of the cast design on the front of the muzzle, suggest that the barrel was cast muzzle-downwards.

3. The back end of the breech ( 5 and 6 ) is harder than the front end (4 and 7) for the same reason. The screw-thread is harder (3) on account of having been finished by cold-working. This, and the presence of tinrich phases, as well as traces of risers on the flat end, confirm that the breech was also cast open-end down.

It has been suggested by Guilmartin that European cannon (unlike Turkish ones) were cast muzzle uppermost so that their muzzles were consequently poor in tin. ${ }^{17}$ Of course, if they were cast that way, then it would result in their breeches being poor in tin. He also comments on the considerable variation in compositions as given by mass spectroscopy. Determining average chemical compositions will not, by itself, elucidate casting techniques, but only differences in composition within one cannon.

Electron microanalysis shows that the $\alpha$ phase in most of the specimens has the same $\mathrm{Cu}: \mathrm{Sn}$ ratio (except for 4 which has markedly more tin than the others) about $8 \% S n$.

The gray particles occurring in many specimens are copper sulphide. The eutectoid areas in specimen 5 contained about $34 \% \mathrm{Sn}$; this was probably the $\delta$ phase in a $\alpha \delta$ eutectoid.

${ }^{17}$ J. F. Gunimartin, Gunpowder and galley's, Cambridge, 1974, 287. 
It is suggested that the average composition is probably fairly close to the $11 \%$ ratio of the raw materials supplied to the Tophane in the following century.

\section{ACKNOWLEDGEMENTS}

This rescarch bas been assisted by an award from the British Academy, to whom the authors would like to express their gratilude. It would not bave been possible without the enthusiastic co-operation of the Keeper of Firearms at the Tower of London, Mr. Howard Blackmore, and his colleagues, Mr. E. Smith and Mr. A. Davies. Electron microanalysis was undertaken at the Metallurgy Department of the University of Surrey, via the good offices of Dr. W. H. Eaton. Dr. C. J. Heywood of the School of Oriental and African Studies, London University made mumerous valuable suggestions about the Topbane, and A. D. Williams provided assistance with the photograpby. 


\section{TURKISH CANNON FROM THE DARDANELLES (CAPTIONS)}

\section{SAMPLE 1}

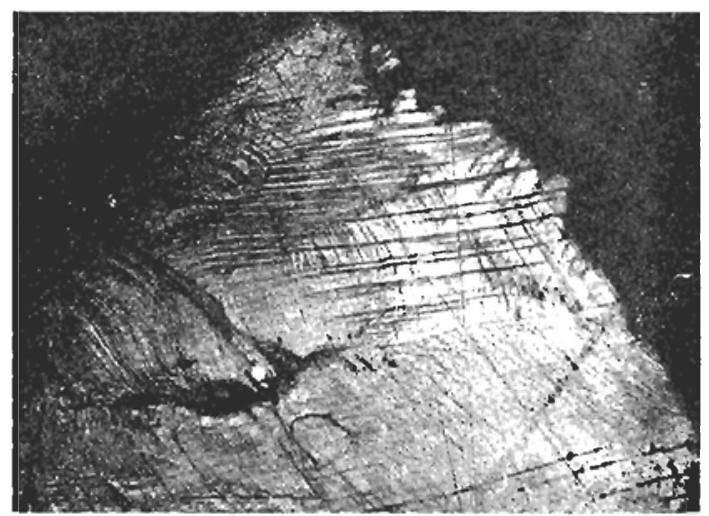

Sample $1 \times 100$. Many slip bands in complex patterns. Sudden change in deformation markings shows at grain boundaries.

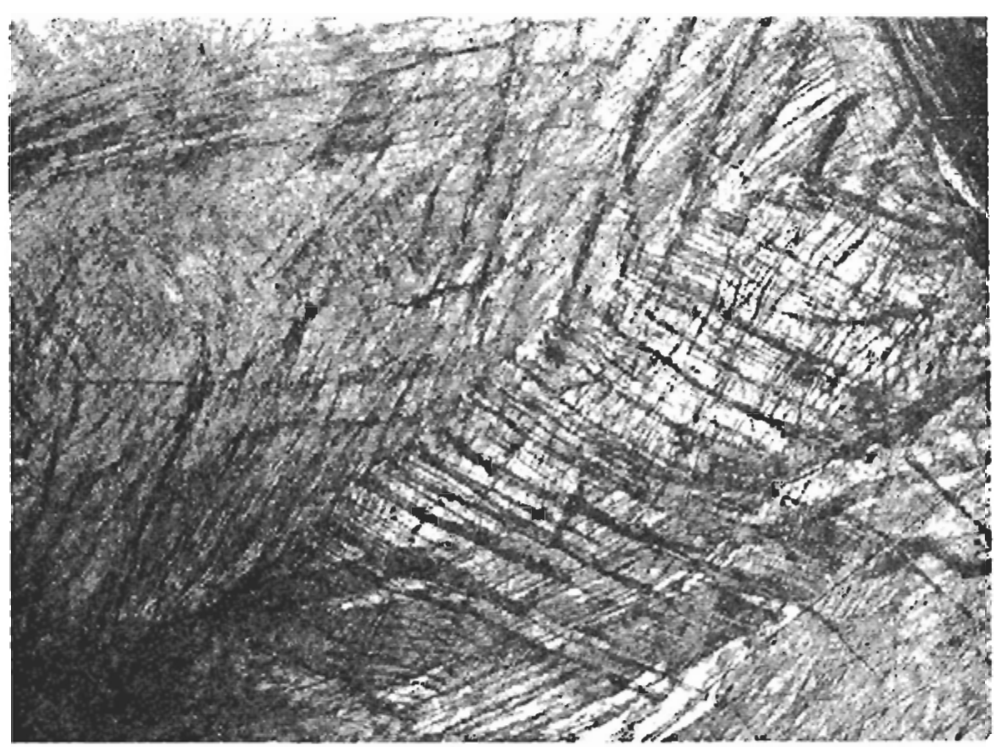

Sample $1 \times 400$. 


\section{SAMPLE 2}

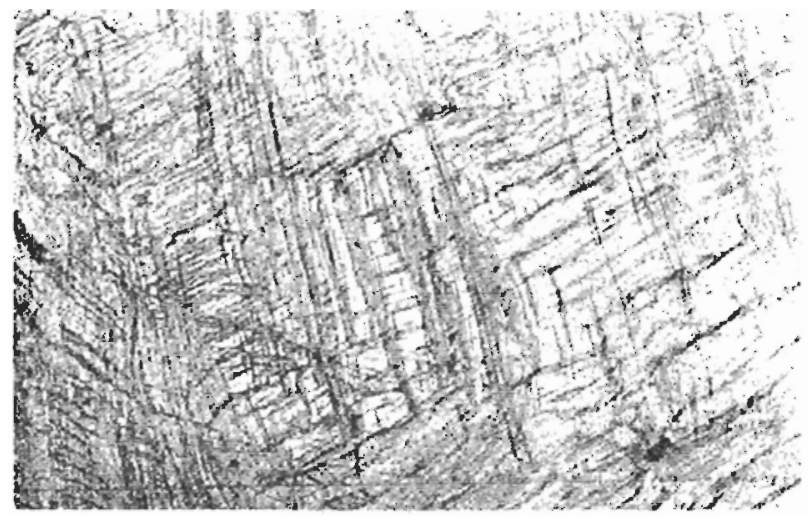

Sample $2 \times 400$. Many slip bands, in complex patterns.

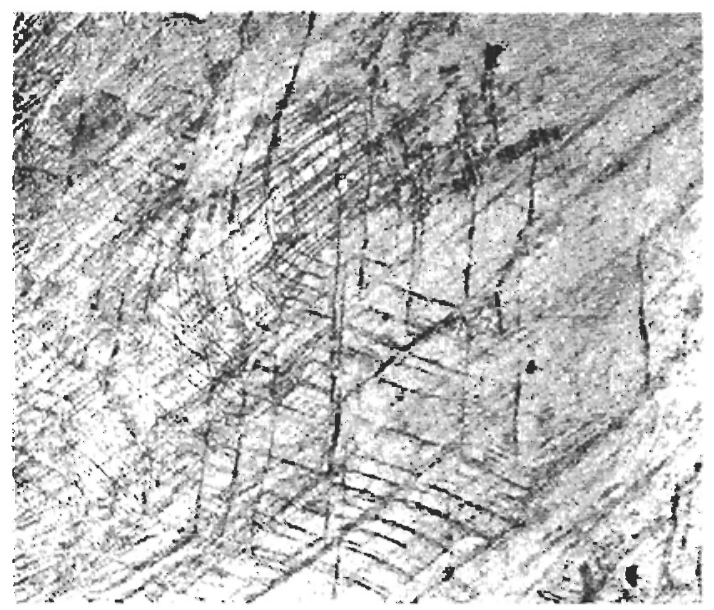




\section{SAMPLE 3}

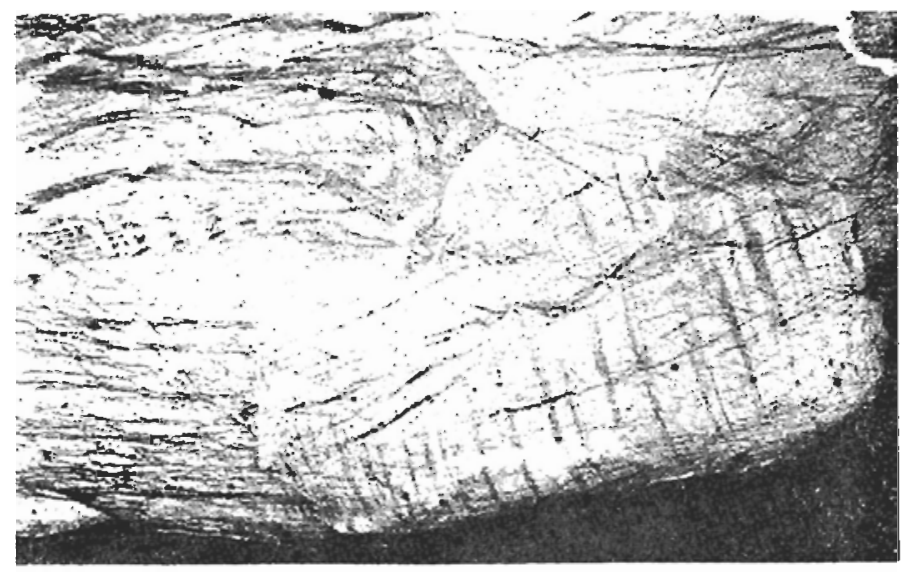

Sample $3 \times 100$. Quite large grains with a varied and complex strain patterns often resembling a flow pattern superimposed on fine initial slip bands.

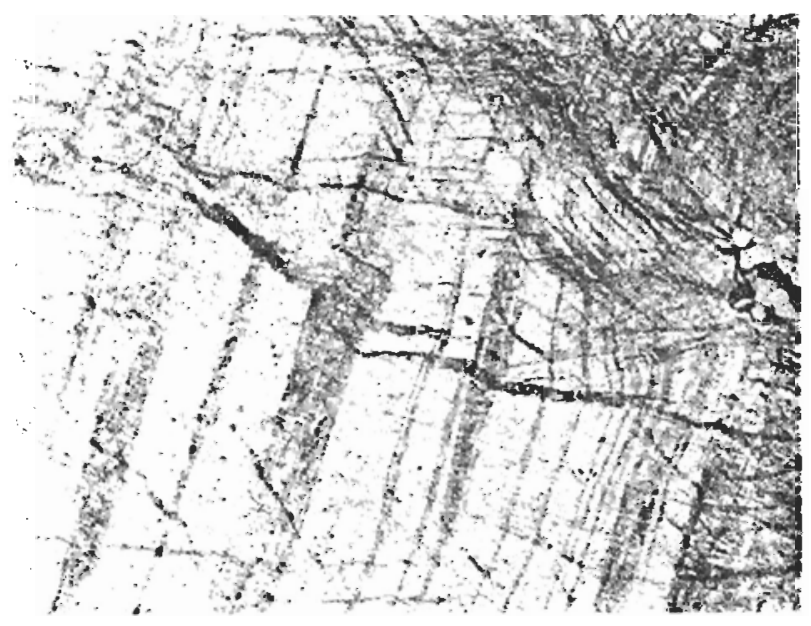

Sample $3 \times 400$. Note slaggy inclusion. 


\section{SAMPLE 4}

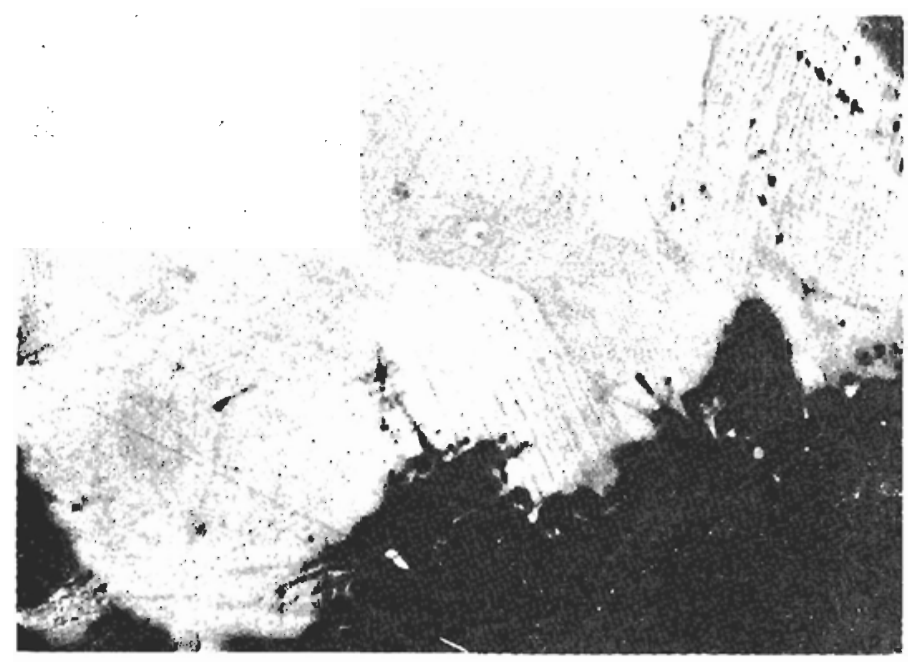

Sample $4 \times 100$.

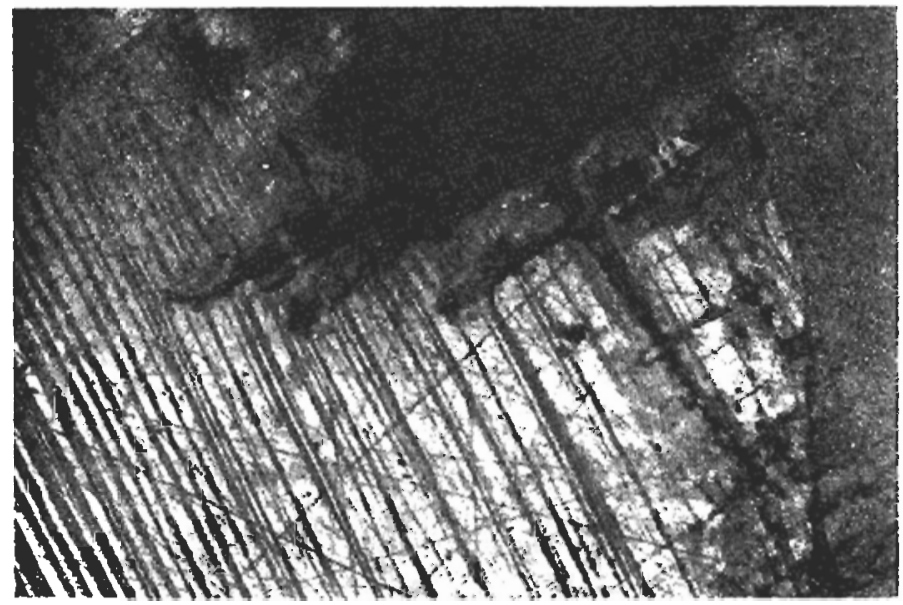

Sample $4 \times 400$. Note interdendritic cavitics. 


\section{SAMPLE 5}

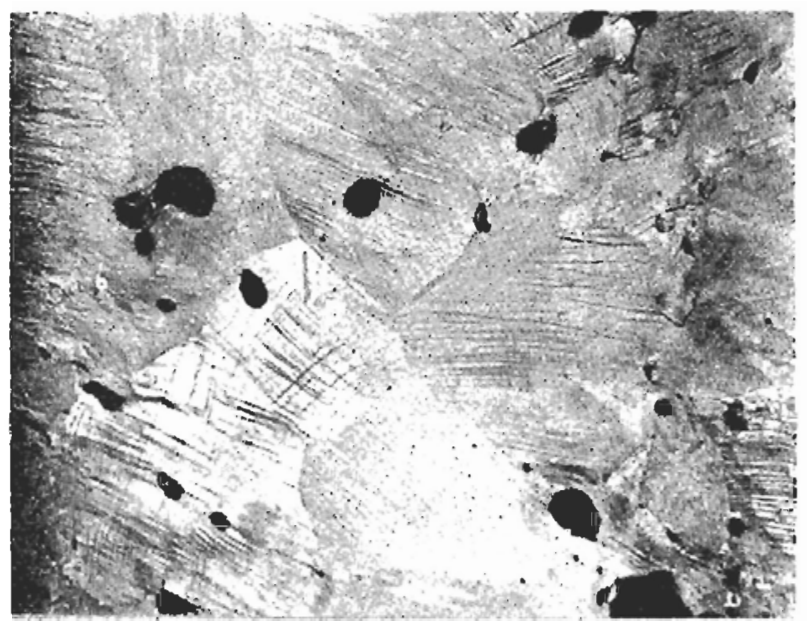

Sample $5 \times 100$. Dark areas are cavities.

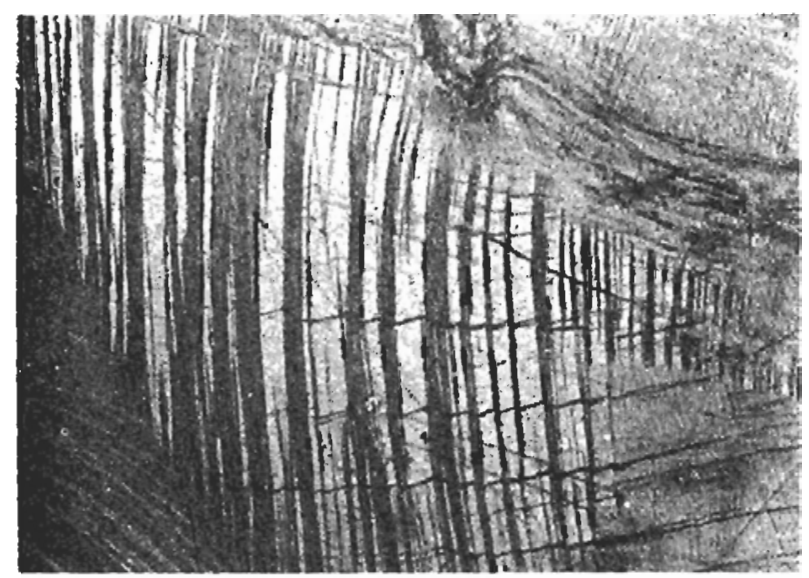

Sample $5 \times 400$. 


\section{SAMPL.E 6}

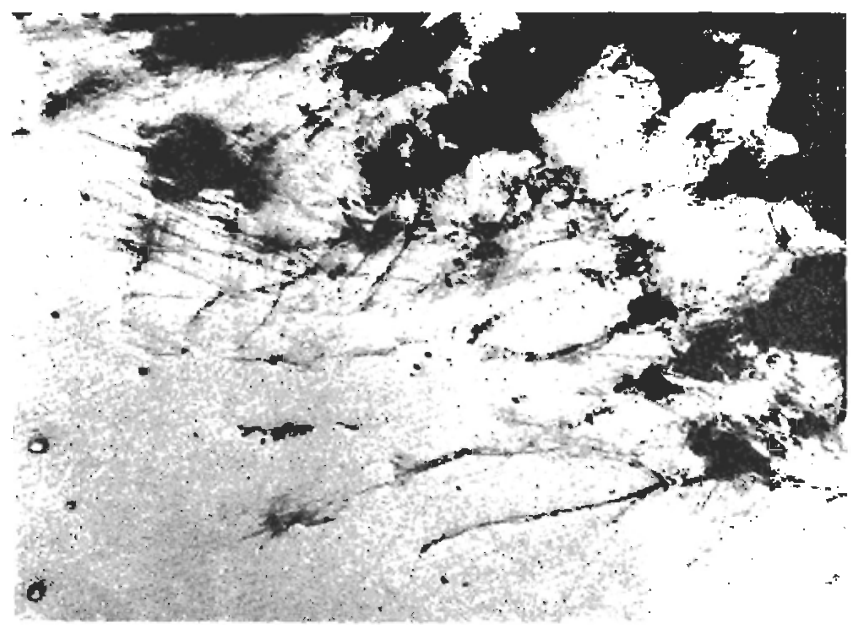

Sample $6 \times 100$ (unetched). Note light-grey inclusions of hightin phase, and microcracks.

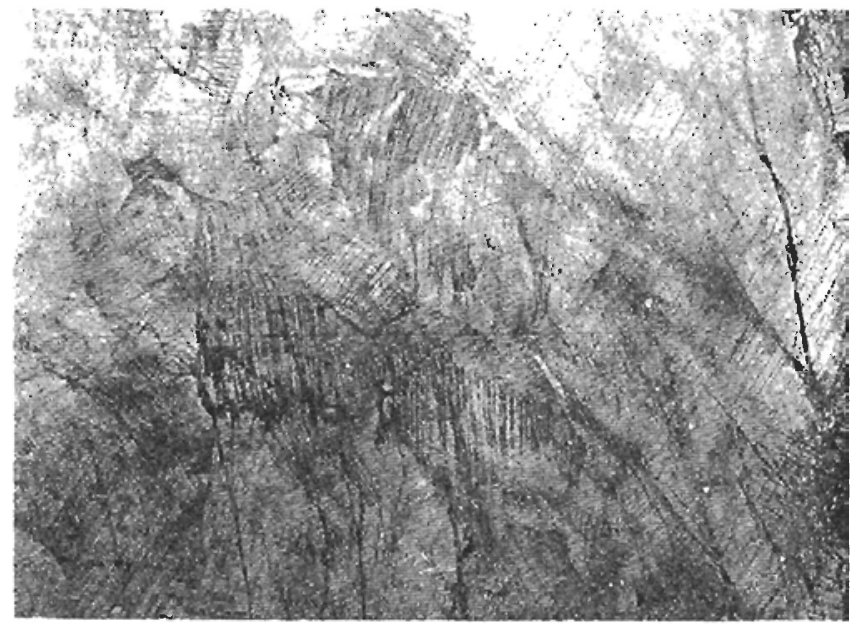

Sample $6 \times 400$. Numerous slip lines, as well as cracks. 


\section{SAMPLE 7}

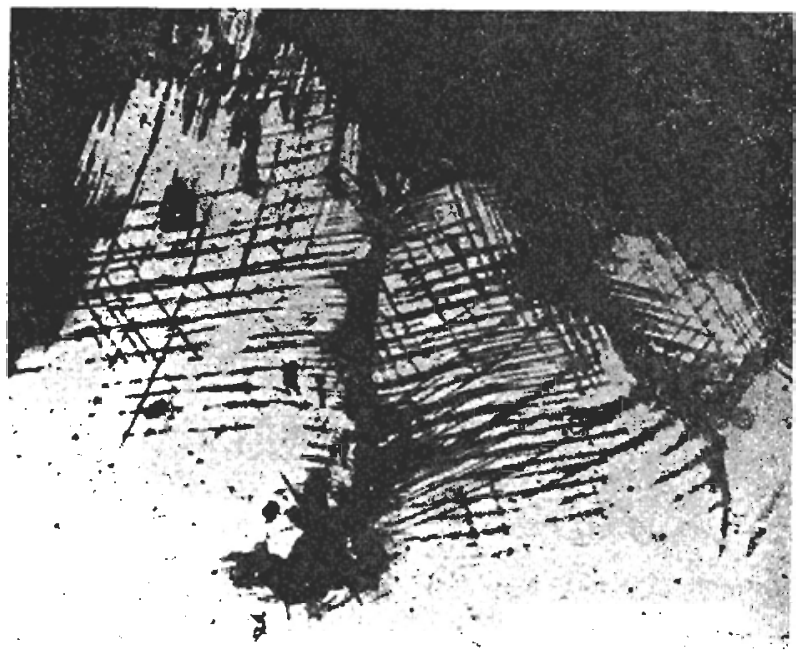

Sample $7 \times 100$ (unctched). Note microcracks in regular patterns.

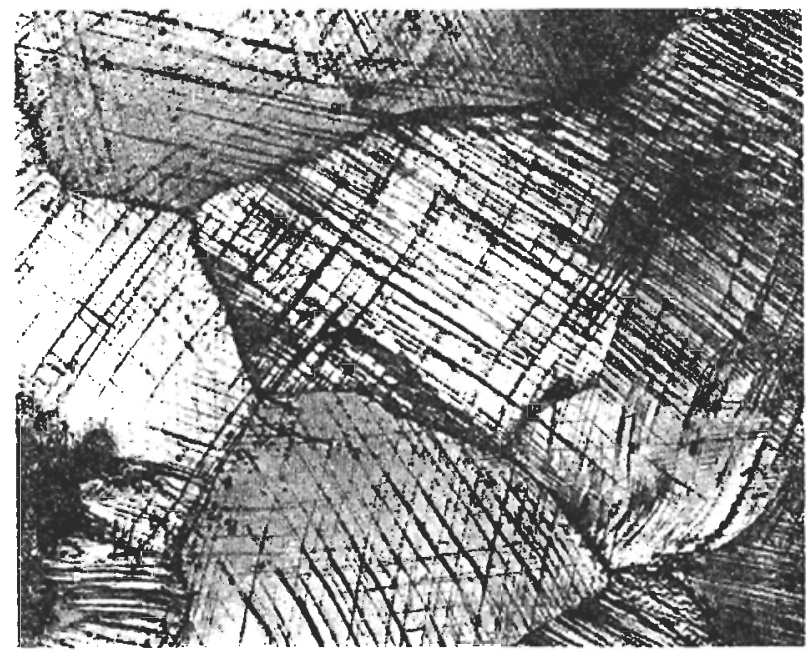

Sample $7 \times 400$ (etched). 


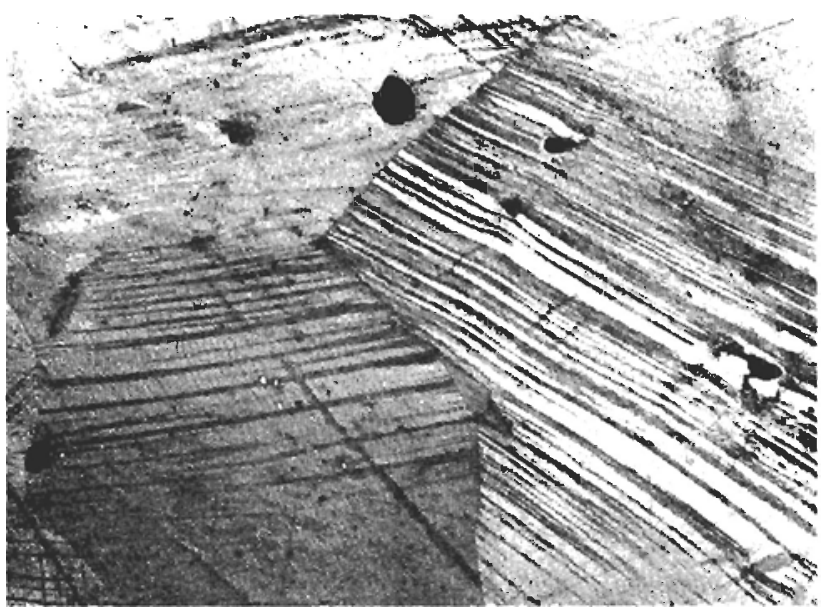

Sample $7 \times 400$. Note cavities (black areas) and light grey (high-tin) inclusions.

\section{SAMPLE 8}

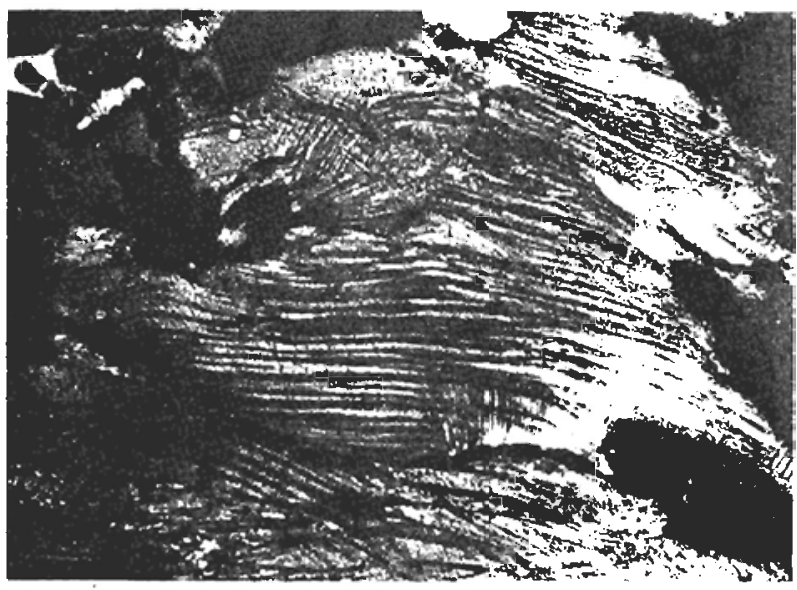

Sample $8 \times 100$.

\section{2}




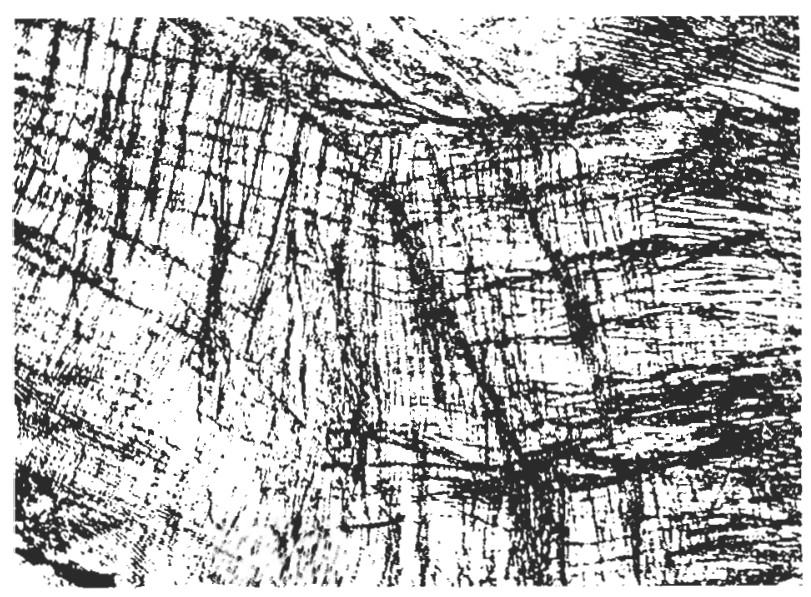

Sample $8 \times 400$. Diagonal lines are merely polishing scratches.

\section{SAMPLE 9}

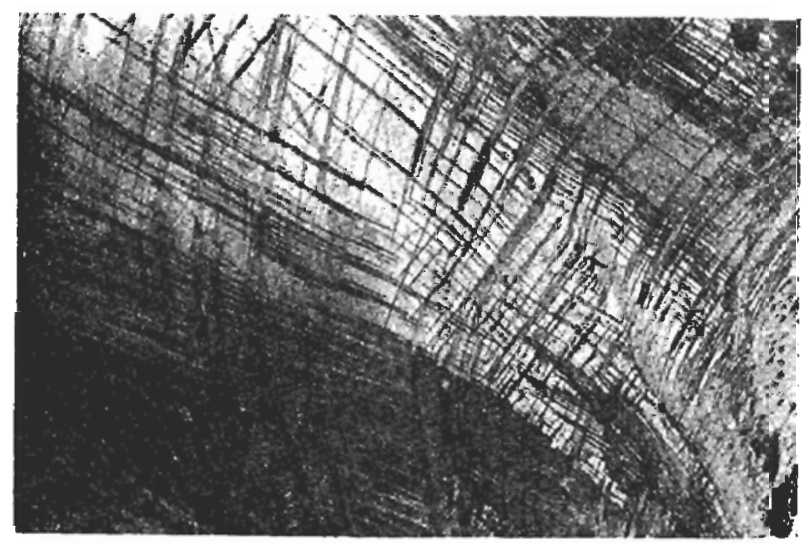

Sample $9 \times 400$. 


\section{SAMPLE 5}

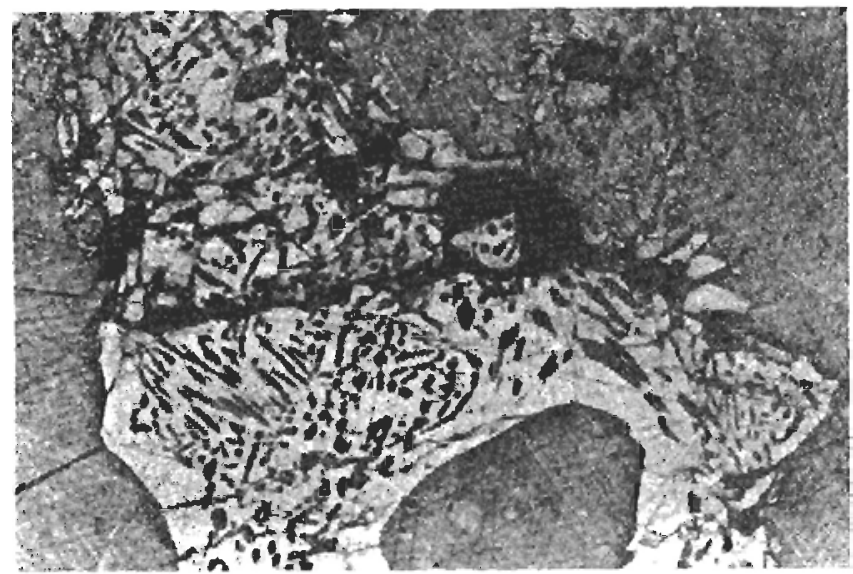

Sample $5 \times 800$. An arca of tin rich eutectoid (ws) in a copperrich matrix. N. B. Two phases are visible in the eutectoid, which is much harder than the matrix, and may have formed at the top of the casting because deliberate late additions of tin caused a higher local tin content. There is also a trace of silver present (detected by electron microanalysis).

\section{SAMPLE 10}

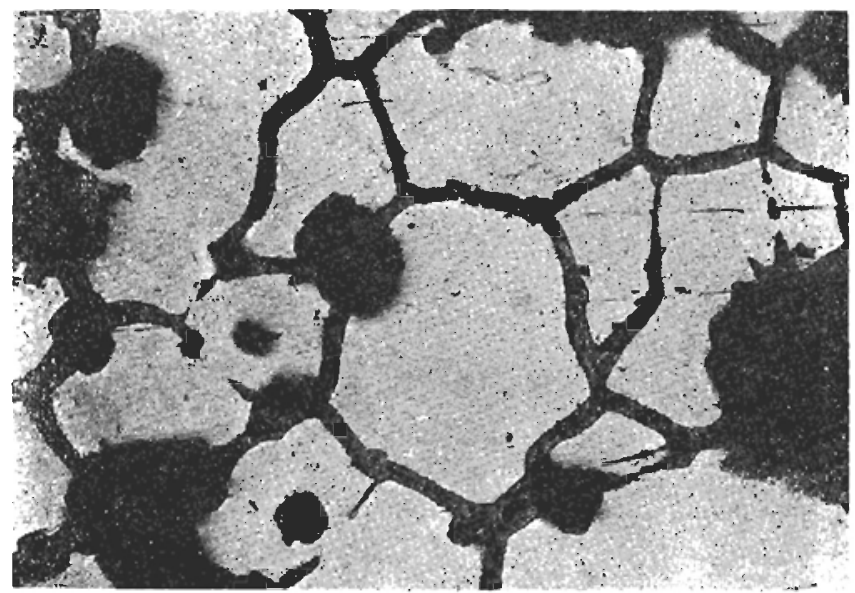

Sample $10 \times 100$. Large equiaxed grains, without slip bands, surrounded by a thick intergranular network of slaggy material (according to electron microanalysis, mostly copper oxide $\mathrm{Cu}_{2} \mathrm{O}$ ). 


\section{SAMPLE 11}

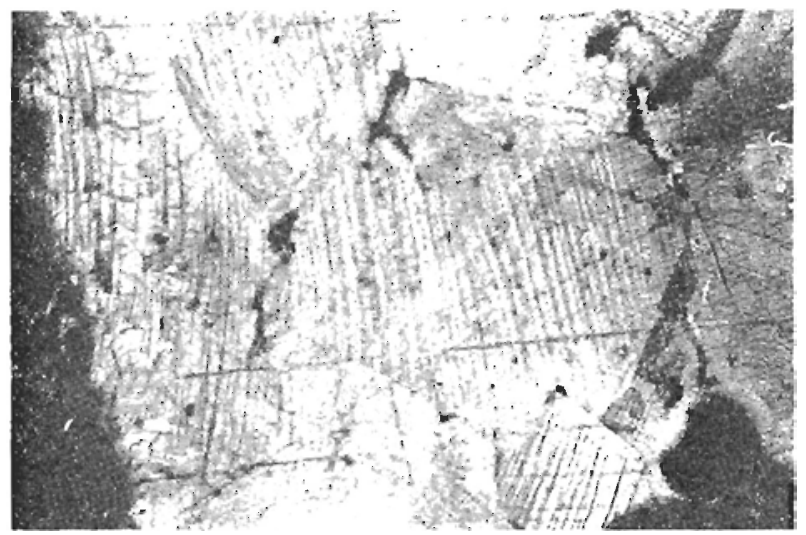

Sample $11 \times 100$. 